\title{
Towards a Definition of Harmless Nanoparticles from an Environmental and Safety Perspective
}

\author{
Xueyan Cui, ${ }^{1,2}$ Jun Yin, ${ }^{1,2}$ Ying Lin, ${ }^{1,2} \mathrm{Na} \mathrm{Li,}{ }^{1,2}$ Meizhen Wang, ${ }^{1,2}$ and Dongsheng Shen ${ }^{1,2}$ \\ ${ }^{1}$ School of Environmental Science and Engineering, Zhejiang Gongshang University, \\ Hangzhou 310012, China \\ ${ }^{2}$ Zhejiang Provincial Key Laboratory of Solid Waste Treatment and Recycling, \\ Hangzhou 310012, China \\ Correspondence should be addressed to Na Li; coincidence625@163.com
}

Received 15 October 2016; Accepted 2 November 2016

Academic Editor: Henryk Kozlowski

Copyright (C) 2016 Xueyan Cui et al. This is an open access article distributed under the Creative Commons Attribution License, which permits unrestricted use, distribution, and reproduction in any medium, provided the original work is properly cited.

The rapid development of nanoparticles (NPs), such as silicon nanoparticles ( $\mathrm{Si} N P s)$ and ferric oxide nanoparticles $\left(\mathrm{Fe}_{2} \mathrm{O}_{3} \mathrm{NPs}\right.$ ), and their use in myriad commercial applications have raised questions of their potential impacts on wastewater treatment systems. In this study, we investigated the consequences of the presence of $\mathrm{Si}$ NPs and $\mathrm{Fe}_{2} \mathrm{O}_{3}$ NPs in the denitrification of anoxic sludge. $\mathrm{Fe}_{2} \mathrm{O}_{3} \mathrm{NPs}$, at a concentration up to $50 \mathrm{mg} / \mathrm{L}$, had no significant impact on nitrate removal, whereas Si NPs, at concentrations up to $50 \mathrm{mg} / \mathrm{L}$, increased the rate of nitrate removal. We used transmission electron microscopy (TEM) to investigate the effect of Si NPs and $\mathrm{Fe}_{2} \mathrm{O}_{3}$ NPs. Si NPs exposure enhanced the abundance of narG-1 gene, which might promote nitrate removal process directly. Finally, we reviewed and identified the specific properties of a variety of NPs responsible for toxicity and found NPs larger than about $100 \mathrm{~nm}$ and without ion release in general possible to energy safety and nontoxic or low toxic to environment. Our results provide useful information to understand the response of anoxic sludge to Si NPs and $\mathrm{Fe}_{2} \mathrm{O}_{3} \mathrm{NPs}$ in complex environmental matrix as well as potent support for wide use of the environmentally friendly NPs.

\section{Introduction}

With the rapid innovation and commercialization in the field of nanotechnology, nanoparticles (NPs) have been used in an increasing number of consumer and industrial products, as NPs unique size-dependent physicochemical properties [1] present commercial advantages. Many studies have shown that the NPs can be toxic to environmental microbes, plants, animals, and even human cells [2-6].

The increasing utilization of products containing NPs results in the release of NPs into sewage which ultimately enters wastewater treatment plants (WWTP). WWTPs are the last barriers that can prevent the release of NPs into the environment $[7,8]$. Previous toxicological studies have shown that $\mathrm{Ag}, \mathrm{CuO}$, and $\mathrm{ZnO}$ NPs could induce significant growth inhibition of bacteria, mammalian cells, fish, and crustaceans [9]. The evidence for effects on wastewater treatment is decidedly mixed: one publication demonstrated that $\mathrm{ZnO}$ NPs could induce acute effects on wastewater nitrogen and phosphorus removal and impair biological phosphorus removal [10]. Another showed that Ag NPs caused inhibition of biogas production and a slight inhibition in the action of other biomasses [11]. However, $\mathrm{TiO}_{2} \mathrm{NPs}$ were reported to have no obvious impacts on biological nitrogen removal after short-term exposure [12]. Similarly, $\mathrm{TiO}_{2}$ and $\mathrm{Au}$ NPs caused only limited or no inhibition for tested biomasses [11]. Different kinds of NPs have different toxic because of their own characteristics.

NPs with diameter below $30 \mathrm{~nm}$ can be readily internalized by cells and will potentially be toxic to the cell. However, little research has explored the combination of nontoxicity of NPs to both eukaryotic (such as mammalian or fish) cells and the impacts on microbial functions. Herein, we explore the impact of silicon and iron oxide nanoparticles, which has 
been generally shown to be nontoxic to certain wastewater treatment biofunctions. Si NPs are a new generation of optoelectronic semiconductor materials with a wide gap to semiconductors and also high power laser source materials. $\mathrm{Fe}_{2} \mathrm{O}_{3}$ NPs are widely utilized as pigments [13] and have attracted considerable attention due to their promising potential in biomedical applications because of their superparamagnetic properties [14] and use in nutritional [15] applications. Under these circumstances, these two kinds of NPs showed low toxicity $[16,17]$.

In this study we investigated the effects of Si NPs and $\mathrm{Fe}_{2} \mathrm{O}_{3} \mathrm{NPs}$ on nitrate removal in wastewater sludge. Furthermore, we assayed interactions between the NPs and bacterial cells using transmission electron microscopy (TEM) visualization and measurement of reactive oxygen species. These studies identify some distinguishing features of interaction between nontoxic NPs and organisms.

\section{Materials and Methods}

2.1. Nanoparticles. Si NPs and $\mathrm{Fe}_{2} \mathrm{O}_{3}$ NPs used in this study were purchased from Chaowei Nanomaterials (Shanghai) and Aladdin, respectively. In this study, the NPs stock suspension (100 mg/L) was prepared by adding $100 \mathrm{mg}$ of NPs to $1 \mathrm{~L}$ of Milli-Q water, followed by $30 \mathrm{~min}$ of ultrasonication $\left(25^{\circ} \mathrm{C}, 250 \mathrm{~W}, 40 \mathrm{kHz}\right)$. The primary particle size of the Si NPs and $\mathrm{Fe}_{2} \mathrm{O}_{3}$ NPs was characterized with transmission electron microscope (TEM) (JEOL JEM-1230, Japan) operated at $80 \mathrm{kV}$. The average diameter of the particles and zeta potential in the stock suspension was measured by dynamic light scattering (DLS) and laser Doppler microelectrophoresis using a Malvern Zetasizer Nano ZS90 (Malvern Instruments, UK).

2.2. Operation Conditions of Sequencing Batch Reactors (SBR). Activated sludge was obtained from the Qige Wastewater Treatment Plant (Hangzhou, China) and cultivated in the anoxic parent SBR with a working volume of $12 \mathrm{~L}$. The SBR was operated at $25^{\circ} \mathrm{C}$ with three cycles each day. The mixed liquor suspended solid (MLSS) was kept at a constant concentration of $3.5 \mathrm{~g} / \mathrm{L}$. Synthetic wastewater, consisting of $216.5 \mathrm{mg} \mathrm{KNO}_{3}, 2.08 \mathrm{mg} \mathrm{KH}_{2} \mathrm{PO}_{4}, 1.76 \mathrm{mg} \mathrm{K} \mathrm{K}_{2} \mathrm{HPO}_{4}$, $4 \mathrm{mg} \mathrm{MgSO}_{4} \cdot 7 \mathrm{H}_{2} \mathrm{O}, 0.96 \mathrm{mg} \mathrm{NaCl}, 1.12 \mathrm{mg} \mathrm{CaCl}_{2}$, and $1.92 \mathrm{mg} \mathrm{FeCl}_{3} \cdot 6 \mathrm{H}_{2} \mathrm{O}$ (all per liter), was used to simulate nitrate-contaminated water. In this synthetic wastewater, trace elements with components of $1000 \mu \mathrm{g}$ EDTA, $300 \mu \mathrm{g}$ $\mathrm{H}_{3} \mathrm{BO}_{3}, 600 \mu \mathrm{g} \mathrm{CoCl} \cdot 6 \mathrm{H}_{2} \mathrm{O}, 30 \mu \mathrm{g} \mathrm{MnCl}_{2} \cdot 4 \mathrm{H}_{2} \mathrm{O}, 30 \mu \mathrm{g}$ $\mathrm{Na}_{2} \mathrm{MO}_{4} \cdot 2 \mathrm{H}_{2} \mathrm{O}, 10 \mu \mathrm{g} \mathrm{CuCl} \cdot \mathrm{H}_{2} \mathrm{O}, 70 \mu \mathrm{g} \mathrm{ZnSO} \cdot 7 \mathrm{H}_{2} \mathrm{O}$, and $20 \mu \mathrm{g} \mathrm{NiCl} \cdot 6 \mathrm{H}_{2} \mathrm{O}$ were supplied (again, all per liter). The $\mathrm{pH}$ was controlled at $7.0 \pm 0.5$; dissolved oxygen (DO) was maintained below $0.5 \mathrm{mg} / \mathrm{L}$.

To conduct the experiments, $5600 \mathrm{~mL}$ of mixture was withdrawn from the parent SBR, centrifuged at $10000 \times \mathrm{g}$ for $5 \mathrm{~min}$, and resuspended in $800 \mathrm{~mL}$ of deionized (DI) water. The $0,5,20$, and $50 \mathrm{mg} / \mathrm{L}$ Si NPs were prepared in 4 reactors by adding $0,35,140$, and $350 \mathrm{~mL}$ of Si NPs stock suspension $(100 \mathrm{mg} / \mathrm{L})$, respectively. The $0,5,25$, and $50 \mathrm{mg} / \mathrm{L} \mathrm{Fe}_{2} \mathrm{O}_{3} \mathrm{NPs}$ were prepared in 4 reactors by adding $0,35,175$, and $350 \mathrm{~mL}$ of $\mathrm{Fe}_{2} \mathrm{O}_{3}$ NPs stock suspension (100 mg/L), respectively. Then, $100 \mathrm{~mL}$ of resuspended sludge and $50 \mathrm{~mL}$ of concentrated synthetic wastewater were fed into each reactor. DI water was added to make the final volume $700 \mathrm{~mL}$. The initial $\mathrm{pH}$ was $7.0 \pm 0.5$. All reactors were bubbled with nitrogen gas for $5 \mathrm{~min}$ and DO was maintained below $0.5 \mathrm{mg} / \mathrm{L}$. The reactors were fully mixed with magnetic stirrer.

2.3. Determination of Reactive Oxygen Species (ROS) Production Induced by NPs. Intracellular ROS production was determined using a Mouse ROS ELISA Kit (Shanghai Chuanxiang). Sludge was centrifuged at $10000 \times \mathrm{g}$ for $5 \mathrm{~min}$ and washed with $0.1 \mathrm{M}$ phosphate buffer ( $\mathrm{pH}$ 7.4) for 3 times. The sludge particles were resuspended in $0.1 \mathrm{M}$ phosphate and then ultrasonic broken for $3 \mathrm{~s}$ on ice, after $5 \mathrm{~s}$ static time, and ultrasonic broken for $3 \mathrm{~s}$ on ice again and this process will be repeated 100 times. The solution was centrifuged at $10000 \times \mathrm{g}$ for $10 \mathrm{~min}$ in $4^{\circ} \mathrm{C}$. We added $50 \mu \mathrm{L}$ of the suspended sample per well in a 96-well plate and then $100 \mu \mathrm{L}$ of HRP-avidin and then covered the microtiter plate, incubated for $1 \mathrm{~h}$ at $37^{\circ} \mathrm{C}$. We aspirated each well and washed 5 times with wash buffer $(200 \mu \mathrm{L})$. After the last wash, remaining wash buffer was removed by aspiration. Then $50 \mu \mathrm{L}$ of solution $\mathrm{A}$ and $50 \mu \mathrm{L}$ of solution B were added to each well, incubated for $15 \mathrm{~min}$ at $37^{\circ} \mathrm{C}$. Finally, add $50 \mu \mathrm{L}$ of stop solution to each well and determine the optical density of each well within $15 \mathrm{~min}$, using a microplate reader $(\lambda=450 \mathrm{~nm})$.

2.4. Transmission Electron Microscopy. Visual characterization of interior morphology of sludge bearing $\mathrm{Si}$ and $\mathrm{Fe}_{2} \mathrm{O}_{3}$ NPs was conducted using TEM. The sludge sample, randomly withdrawn from each reactor, was washed three times with $0.1 \mathrm{M}$ phosphate buffer ( $\mathrm{pH} 7.4$ ), fixed with $2.5 \%$ glutaraldehyde ( $\mathrm{pH} \mathrm{7.2-7.4)} \mathrm{overnight} \mathrm{at} 4^{\circ} \mathrm{C}$, and then washed 3 times with $0.1 \mathrm{M}$ phosphate buffer. Samples were fixed for $2 \mathrm{~h}$ by $1 \%$ osmic acid before being washed for 3 times with $0.1 \mathrm{M}$ phosphate buffer. Samples were dehydrated by serial passage through increasing ethanol concentrations $(30,50,70,90$, and $100 \%, 15$ min per step) and then placed in a mixture of Spurr (2) resin and acetone $(1: 1)$ for $30 \mathrm{~min}$, followed by $2 \mathrm{~h}$ in 2 changes of $100 \%$ resin. Finally, samples were placed in fresh $100 \%$ resin in molds and polymerized at $70^{\circ} \mathrm{C}$ for $8-24 \mathrm{~h} \mathrm{[18].}$ Ultrathin (70-90 nm) sections were cut with a diamond knife for TEM analysis.

2.5. DNA Extraction and Real-Time PCR. Chromosomal DNA of the activated sludge was extracted according to the instructions from the DNA Isolation Kit purchased from BioTeke Corporation (Beijing, China).

Gene expression of NAR, the key enzyme in denitrification, was monitored by real-time PCR. The bacterial gene NAR design primers were as follows: narG-1F $\left(5^{\prime}\right.$ GAC TTC CGC ATG TCR AC- $\left.3^{\prime}\right)$ and narG-1R (5' - TTY TCG TAC CAG GTG GC- $\left.3^{\prime}\right)$, narG-2F ( $5^{\prime}$-CTC GAY CTG GTG GTY GA- $\left.3^{\prime}\right)$, and narG-2R ( $5^{\prime}$-TTY TCG TAC CAG GTS GC-3') [19]. Real-time PCR was run on the Bio-Rad fluorescence quantitative PCR. The volume of $10 \mu \mathrm{L}$ reaction system contained $5 \mathrm{ng}$ of DNA template, $5 \mu \mathrm{L}$ iQ SYBR Green Supermix, and $20 \mathrm{pmol} / \mathrm{L}$ forward and reverse primers. Cycle conditions were as follows: initial denaturation for $10 \mathrm{~min}$ at $95^{\circ} \mathrm{C}$ followed by 40 cycles of $95^{\circ} \mathrm{C}$ for $15 \mathrm{~s}$ and 
annealing/extension at the temperatures $55^{\circ} \mathrm{C}$ and $60^{\circ} \mathrm{C}$ for $1 \mathrm{~min}$. Gene and gene transcript numbers were quantified via comparison to standard curves. Automatic analysis settings were selected to determine the threshold cycle $(\mathrm{Ct})$ values and baseline settings. We used the $2^{-\Delta \Delta \mathrm{Ct}}$ method to calculate the relative quantitative gene expression of NAR gene expression to $16 \mathrm{~s}$ rDNA internal gene expression [20]. 16s rDNA internal gene primers were $338 \mathrm{~F}\left(5^{\prime}\right.$-CCTACGGGAGGCAGCAG- $\left.{ }^{\prime}\right)$ and 518R ( $5^{\prime}$-ATTACCGCGGCTGCTGG-3').

2.6. Analytical Methods. All samples were centrifuged and then filtrated with $0.45 \mu \mathrm{m}$ filter membrane before analysis. The analysis of nitrate-nitrogen $\left(\mathrm{NO}_{3}{ }^{-}-\mathrm{N}\right)$, nitrite-nitrogen $\left(\mathrm{NO}_{2}{ }^{-}-\mathrm{N}\right), \mathrm{COD}$, and MLSS, and mixed liquor volatile suspended solid (MLVSS) was conducted in accordance with standard methods [21].

2.7. Statistical Analysis. All tests were performed in triplicate and the results were expressed as mean \pm standard deviation. An analysis of variance (ANOVA) was used to test the significance of results and $p<0.05$ was considered to be statistically significant.

\section{Results}

3.1. Characterization of Si NPs and $\mathrm{Fe}_{2} \mathrm{O}_{3} \mathrm{NPs}$. We initially characterized the NPs using a combination of electron microscopy and WHAT. TEM images of the Si NPs and $\mathrm{Fe}_{2} \mathrm{O}_{3}$ NPs from the batch used for this study are shown in Figure 1. The average particle sizes of Si NPs and $\mathrm{Fe}_{2} \mathrm{O}_{3}$ NPs were observed as $50-100 \mathrm{~nm}$ and $80-100 \mathrm{~nm}$, respectively. The zeta-potential of Si NPs and $\mathrm{Fe}_{2} \mathrm{O}_{3}$ NPs was -23.23--27.18 and $-12.25--16.65 \mathrm{mV}$. All zeta-potentials were negative, indicating relative stability within a suspension. Si NPs had the lower magnitude zeta-potential, and it suggested that their surface morphology was different. The interactions of anoxic sludge with $50 \mathrm{mg} / \mathrm{L} \mathrm{Si} \mathrm{NPs} \mathrm{and} 50 \mathrm{mg} / \mathrm{L} \mathrm{Fe}_{2} \mathrm{O}_{3}$ NPs were observed in Figure 2, and sludge bulking of the anoxic sludge was caused by $50 \mathrm{mg} / \mathrm{L}$ of $\mathrm{Si} \mathrm{NPs}$. Si NPs and $\mathrm{Fe}_{2} \mathrm{O}_{3}$ NPs did not release any ions (data not shown). Si NPs had the lowest magnitude zeta-potential, which explains the greater extent of agglomeration by $\mathrm{Si}$ NPs than $\mathrm{Fe}_{2} \mathrm{O}_{3}$ NPs. Because zeta-potential of all NPs was between $-10 \mathrm{mV}$ and $-30 \mathrm{mV}$, the NPs were expected to form microscale particle aggregates [22]. The aggregates would become greater in quantity and larger in size with increasing NPs loading concentrations [23], which should lead to the reduction of NPs' effective surface area and surface reactivity and reduce adverse impacts on bacteria.

3.2. Effects of $\mathrm{Si}$ and $\mathrm{Fe}_{2} \mathrm{O}_{3}$ NPs on Nitrate Removal. To study if $\mathrm{Si}$ or $\mathrm{Fe}_{2} \mathrm{O}_{3}$ NPs could alter biological functions, we investigated nitrate removal efficiencies with different concentrations of NP. Nitrate removal with the addition of Si NPs was nearly $100 \%$ at the end of each cycle (Figures 3(a)$3(c))$. Compared to the control, with the increase of Si NPs concentrations from 0 to $50 \mathrm{mg} / \mathrm{L}$, the $\mathrm{NO}_{3}{ }^{-}-\mathrm{N}$ removal efficiency decreased from $90.5 \%$ to $82.8 \%$ at the first hour in the first cycle, but there was no significant difference to the control group $(p>0.05)$. In the third and sixth cycle, the
$\mathrm{NO}_{3}{ }^{-}-\mathrm{N}$ removal efficiencies of $\mathrm{Si} \mathrm{NPs}(5,20$, and $50 \mathrm{mg} / \mathrm{L})$ were higher than that of control group. In the sixth cycle, $50 \mathrm{mg} / \mathrm{L}$ Si NPs had positive effect on the $\mathrm{NO}_{3}{ }^{-}-\mathrm{N}$ removal $(p<0.05)$. Thus, Si NPs appeared to promote nitrate removal or at a minimum and had no deleterious impact on nitrate removal.

Similarly we tested the $\mathrm{NO}_{3}{ }^{-} \mathrm{N}$ removal efficiency in the presence of $\mathrm{Fe}_{2} \mathrm{O}_{3} \mathrm{NPs}$ at concentrations of 5, 25, and $50 \mathrm{mg} / \mathrm{L}$ (Figures 3(d)-3(f)). Nitrate removal efficiency was almost $100 \%$ with exposure of 5, 25, and $50 \mathrm{mg} / \mathrm{L} \mathrm{Fe}_{2} \mathrm{O}_{3} \mathrm{NPs}$ under anoxic conditions, almost the same as those observed in the control test, suggesting that the addition of $\mathrm{Fe}_{2} \mathrm{O}_{3} \mathrm{NPs}$ had no effect on $\mathrm{NO}_{3}{ }^{-}-\mathrm{N}$ removal $(p>0.05)$.

As shown in Figure 2, anoxic sludge exposure to $50 \mathrm{mg} / \mathrm{L}$ of Si NPs caused sludge bulking. Under a limited sludge bulking stage, nutrient removal efficiencies were increased [24]. Previously it was reported that the exposure to $\mathrm{SiO}_{2} \mathrm{NPs}$ induced no evident effects on MSTO and 3T3 cells due to its insolubility [25]. $\mathrm{SiO}_{2} \mathrm{NPs}$ and $\mathrm{TiO}_{2} \mathrm{NPs}$ were found to have no significant effects on nitrogen removal after shortterm exposure due to its insolubility $[12,26]$. Similarly, it is reasonable that no effects of insoluble $\mathrm{Si}$ and $\mathrm{Fe}_{2} \mathrm{O}_{3}$ NPs on nitrogen removal were observed.

3.3. Interaction of Bacterial Cells and NPs. Recently, Herd et al. [27] reported that $\mathrm{SiO}_{2}$ NPs with various geometries have different orientations at the macrophage cell surface, resulting in distinct NP uptake and toxicity mechanisms. We reasoned that bacteria/NPs interactions might explain why $\mathrm{Si}$ and $\mathrm{Fe}_{2} \mathrm{O}_{3} \mathrm{NPs}$ did not negatively influence nitrogen removal efficiency even at high $\mathrm{Si}$ and $\mathrm{Fe}_{2} \mathrm{O}_{3}$ NPs concentrations. TEM was employed to investigate the interaction of sludge and $\mathrm{Si}, \mathrm{Fe}_{2} \mathrm{O}_{3}$ NPs (Figures 4 and 5). We observed that $\mathrm{Si}$ NPs did not enter into bacteria (Figures $4(E)$ and $(G)$ ), and there was no obvious damage to the internal structure of bacteria. Si NPs primarily aggregated around the bacteria. In the first $6 \mathrm{~h}$, Si NPs caused plasmolysis of larger bacteria and some death (Figure 4(F)); however, most bacteria appeared normal after $36 \mathrm{~h}$ (Figure $4(\mathrm{a})$ ). When anoxic sludge was exposed to $\mathrm{Fe}_{2} \mathrm{O}_{3}$ NPs, $\mathrm{Fe}_{2} \mathrm{O}_{3}$ NPs were visibly attached to the cell wall and damaged bacteria at $6 \mathrm{~h}$ (Figures 5(b), (D), (E), and (F)). Strikingly, after incubation with $\mathrm{Fe}_{2} \mathrm{O}_{3}$ NPs $(50 \mathrm{mg} / \mathrm{L})$ for $36 \mathrm{~h}$, bacteria were observed surrounded by massive aggregates of $\mathrm{Fe}_{2} \mathrm{O}_{3}$ NPs (Figure 5(H)). Notably, the majority of bacteria in the sludge system were not affected by NPs $[28,29]$. In previous studies anoxic sludge was shown to contain a variety of bacteria, which had strong defenses against NPs [30]. This would explain why both NPs had no effect on nitrate removal (but not why other NPs did affect nitrate removal).

3.4. ROS Production. NPs could cause oxidative stress and thereby induce oxidative damage to cell membrane [31]. ROS generation is considered to be the primary method by which NPs might be toxic to bacterial cells [32]. High ROS production might lead to the damage of cytoplasmic proteins or cell membrane in human cells [33]. Different NPs produced different amount of ROS, which might explain the different toxicities. 


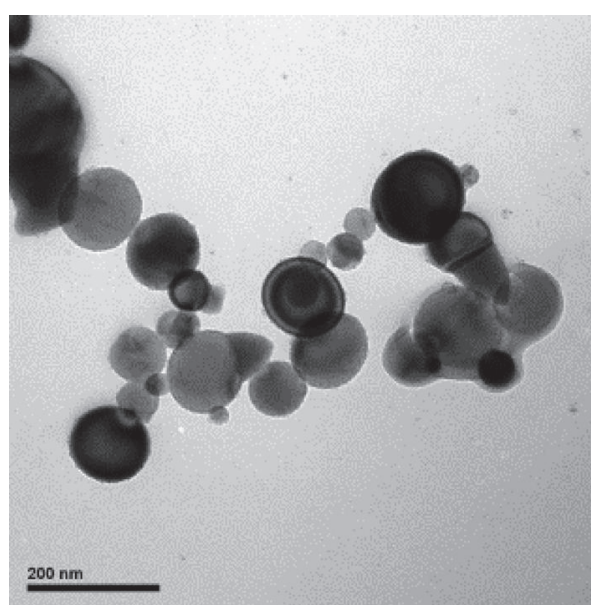

(a)

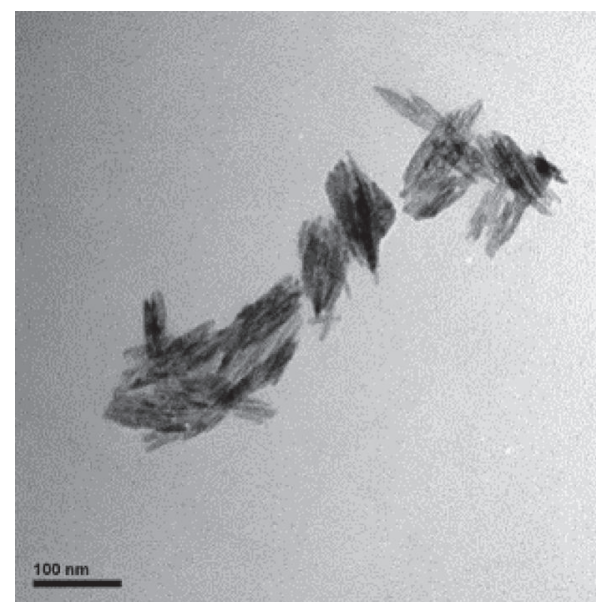

(b)

FIGURE 1: TEM image of the (a) Si NPs and (b) $\mathrm{Fe}_{2} \mathrm{O}_{3}$ NPs used in this study.
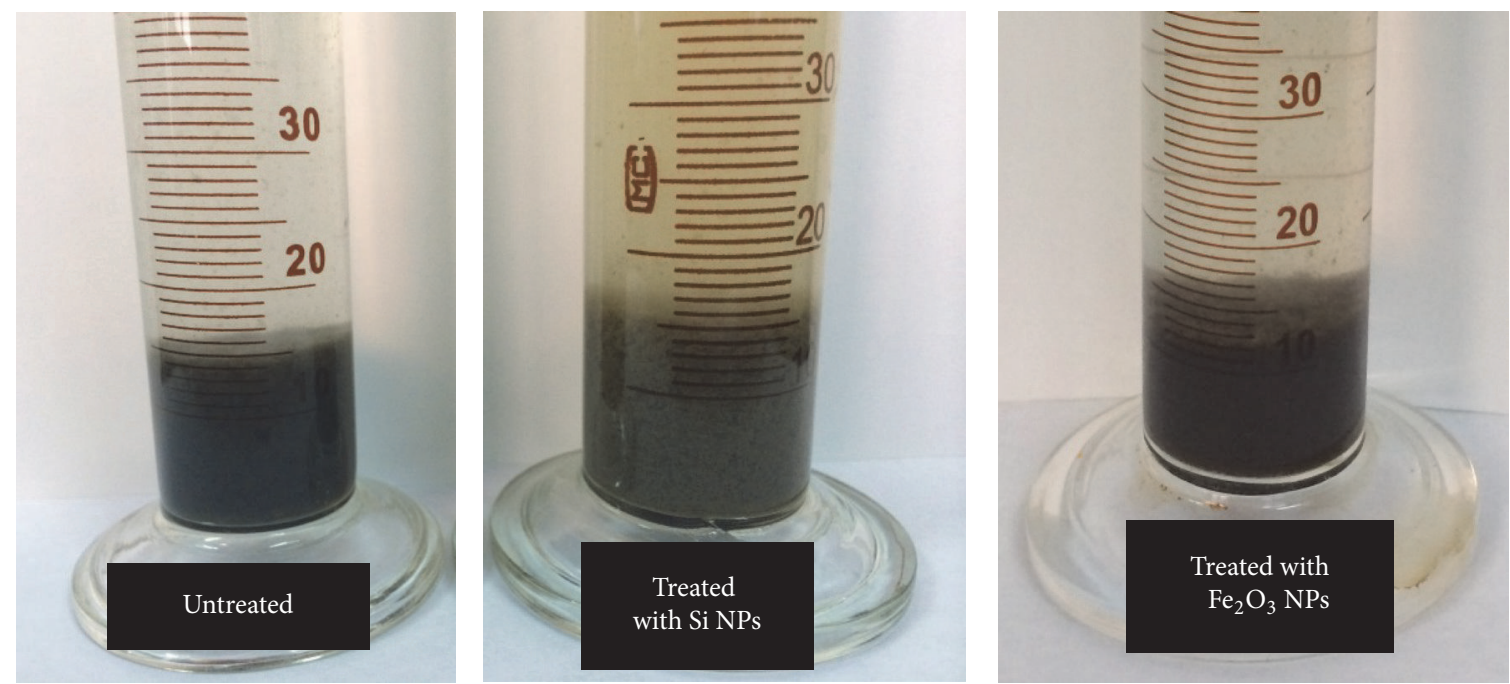

Figure 2: The sludge properties with addition of $50 \mathrm{mg} / \mathrm{L}$ Si NPs and $50 \mathrm{mg} / \mathrm{L} \mathrm{Fe}_{2} \mathrm{O}_{3} \mathrm{NPs}$.

We noted that early in the experiment, before $6 \mathrm{~h}$, there was apparent NP toxicity to bacterial populations (Figure 4). We reasoned that this might be due to ROS production and measured intracellular ROS production was measured. ROS generation of sludge bacteria induced by Si NPs was concentration-dependent for the first two hours of the reaction but decreased and leveled off near controls by $6 \mathrm{~h}$ (Figure 6). The increase in ROS at these early time points was caused by oxidative stress. The initial oxidative stress upon Si NPs (Figure 6) gradually abated in response to the antioxidant defense system of cells. Therefore they effectively resisted the toxicity of Si NPs and promoted the activity of bacteria inversely. The overall ROS production in the presence of $\mathrm{Fe}_{2} \mathrm{O}_{3}$ NPs was not different $(p>0.05)$ than the control without $\mathrm{Fe}_{2} \mathrm{O}_{3}$ NPs.

According to the result of ROS, $\mathrm{Si}$ and $\mathrm{Fe}_{2} \mathrm{O}_{3}$ NPs had no obvious toxic to sludge. The effect of fullerene NPs aggregate size on ROS production and toxicity toward Vibrio fischeri has been reported [34]. However, there is some disagreement regarding the role of ROS in conveying NPs toxicity. The studies reported that $\mathrm{Cu}$ NPs were prone to induce the oxidative damage of membrane lipids [35] and proteins [36]. Moreover, it has been reported that toxic effects of fullerene NPs are due to direct oxidative damage by NPs without ROS production [37].

3.5. Gene Expression Analysis. We next asked whether the presence of NPs and the effects on bacteria could have an impact on gene expression. We focused on nitrate reductase (NAR), the key enzyme for denitrification. We measured transcription of the genes narG-1 and narG-2 by RT-PCR [19] (Figure 7). We did not detect transcripts from the narG-2 subgroup in the sludge. Si NPs did not affect the abundance of narG-1 gene of sludge bacteria in the first and third cycle $(p>0.05)$ (Figure $7(\mathrm{a}))$. However, $50 \mathrm{mg} / \mathrm{L}$ of Si NPs induced the increased abundance of narG-1 gene $(p<0.05)$ in 

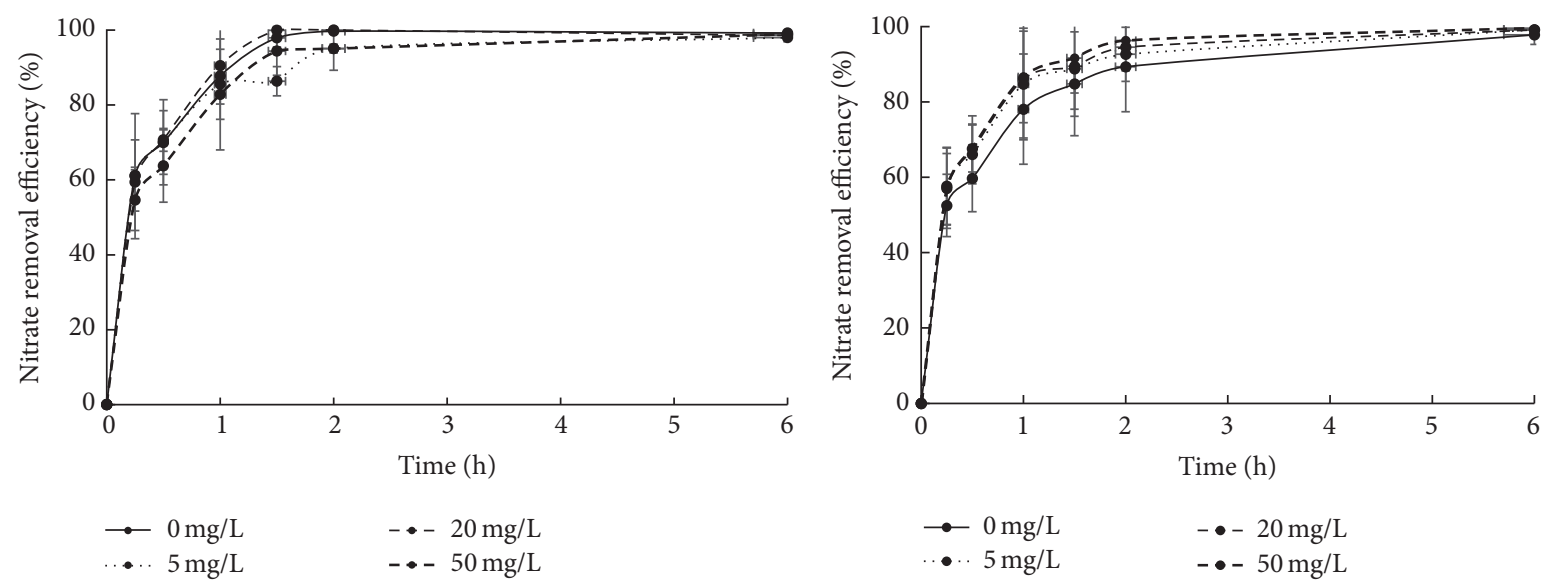

(a)
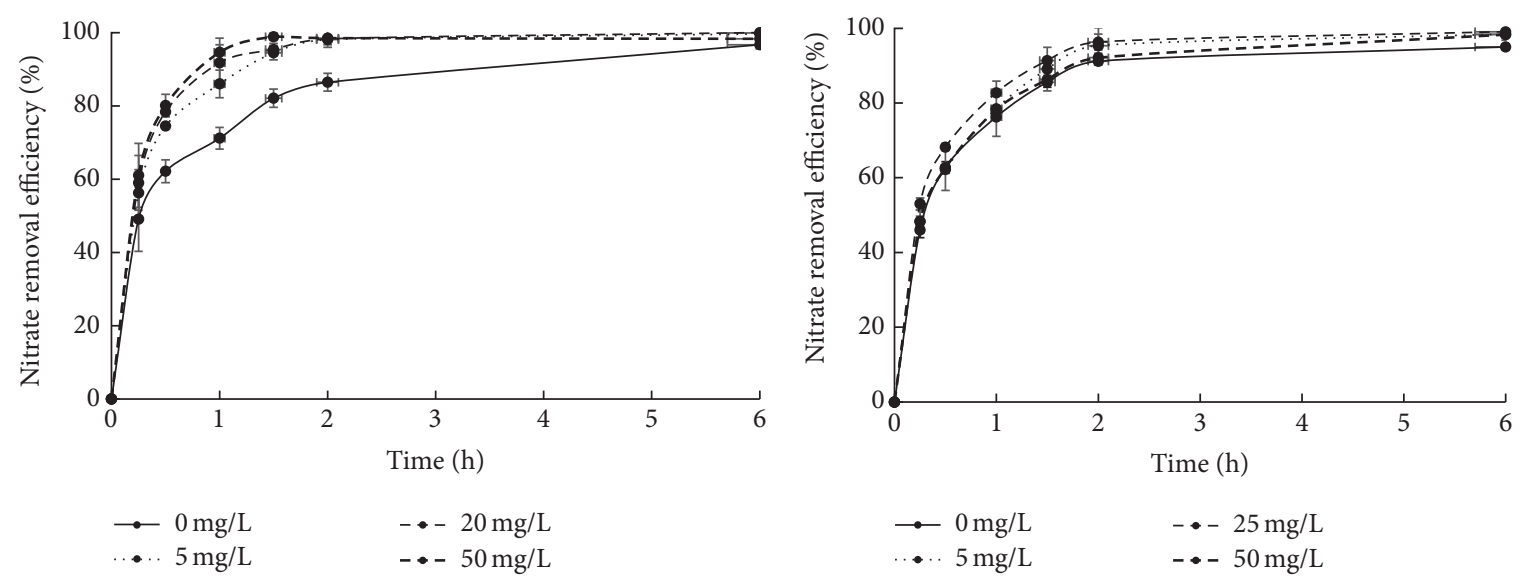

(c)

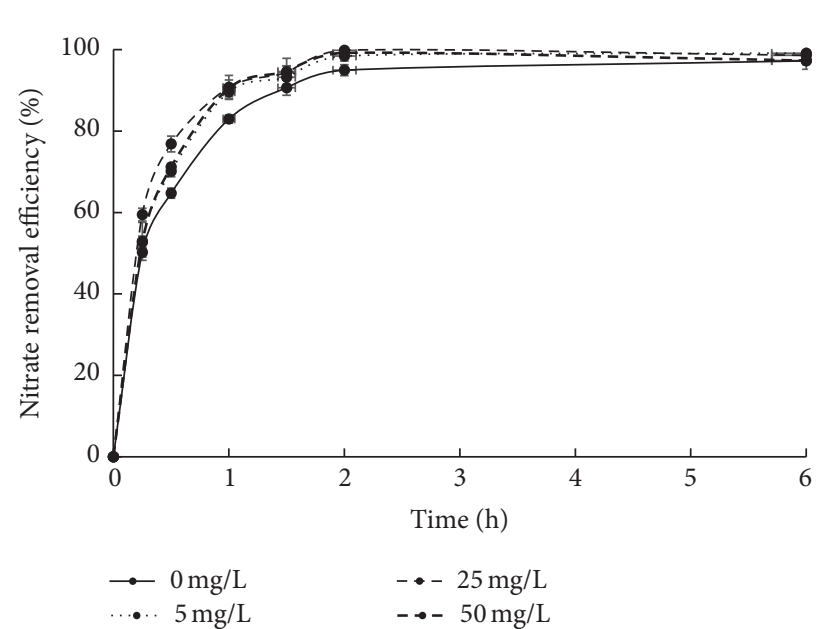

(e)

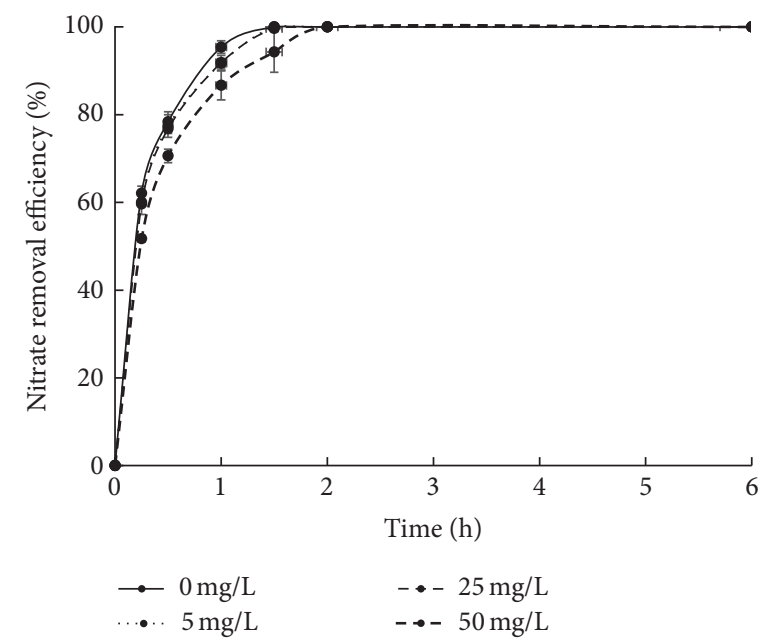

(f)

Figure 3: ((a)-(c)) Nitrate removal efficiency in the reactors with different concentrations of Si NPs. Nitrate removal efficiency of (a) the first cycle, (b) the third cycle, and (c) the sixth cycle. ((d)-(f)) Nitrate removal efficiency in the reactors with different concentrations of $\mathrm{Fe}_{2} \mathrm{O}_{3}$ NPs. Nitrate removal efficiency of (d) the first cycle, (e) the third cycle, and (f) the sixth cycle. Mean \pm standard. 

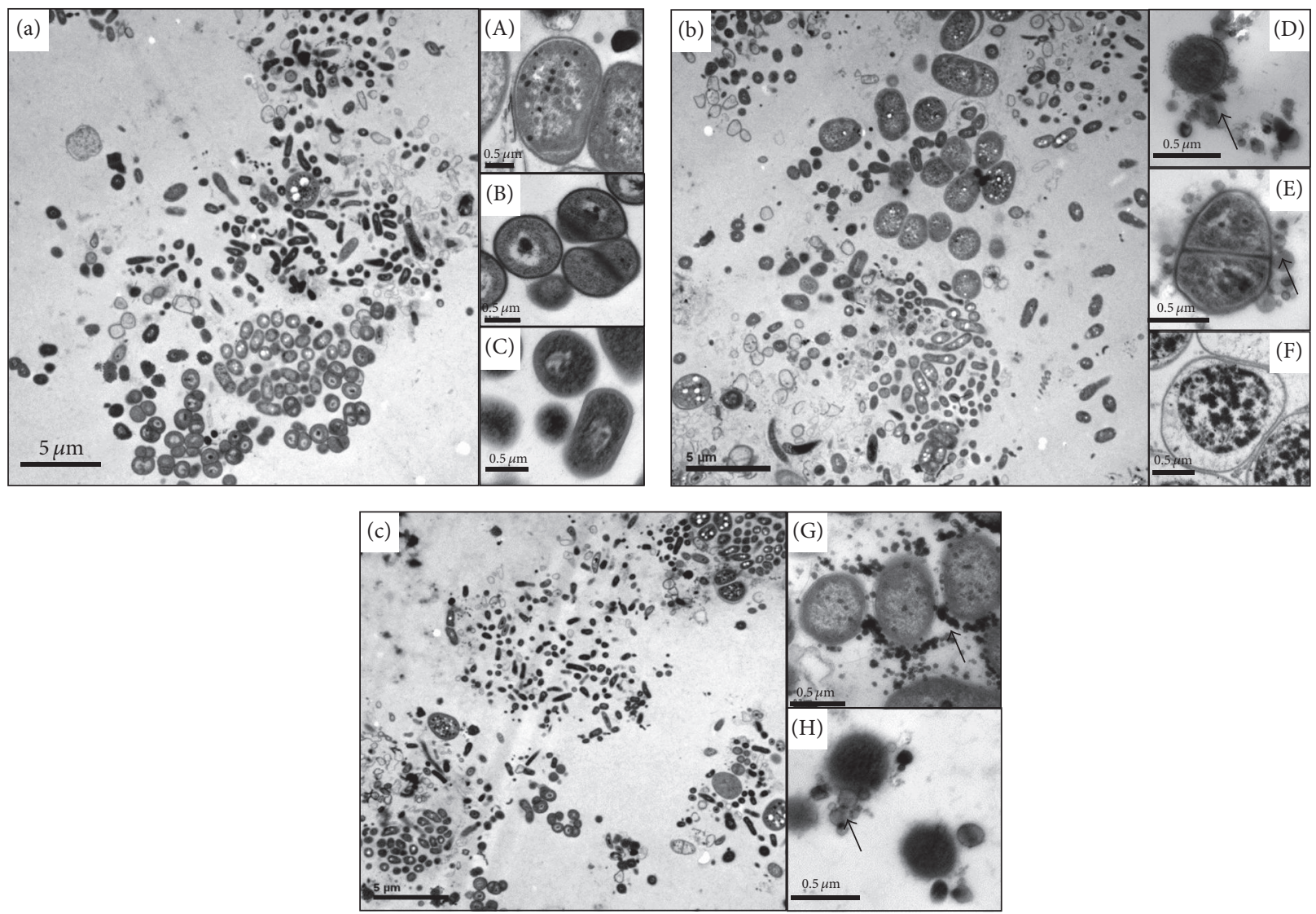

FIGURE 4: TEM image of sludge without (a) or with (b) the addition of $50 \mathrm{mg} / \mathrm{L} \mathrm{Si}$ NPs after $6 \mathrm{~h}$. (a) Inset panels (A)-(C) and (D)-(F) show three kinds of bacteria in the sludge. In panel (c), the reaction was allowed to continue for 36 hours in the presence of Si NPs. The insets (G, $\mathrm{H})$ show bacteria at the $36 \mathrm{~h}$ time point. Arrows indicate Si NPs.

the sixth cycle, which may partly explain the promotion of nitrate removal. By comparison, $\mathrm{Fe}_{2} \mathrm{O}_{3} \mathrm{NPs}$ did not affect the abundance of narG-1 gene in the sludge $(p>0.05)$. The results of RT-PCR were consistent with our previous results on the efficiency of nitrate removal and suggested that that NPs can act to result in the increased expression of denitrification enzymes.

\section{Discussion}

Toxic effects have been observed for many kinds of NPs at a range of concentrations and for a variety of organisms. We collected, analyzed, and summarized the toxicity data from the published literature on NPs. Studies used various measures of toxicity including: minimum inhibitory concentration (MIC), median lethal dose $\left(\mathrm{LD}_{50}\right)$, half maximal effective concentration $\left(\mathrm{EC}_{50}\right)$, half maximal inhibitory concentration $\left(\mathrm{IC}_{50}\right)$, viability, CFU, ROS, and DNA damage. The purpose of reviewing the literature on toxicity was to summarize the physicochemistry characteristics of experimented NPs, so as to distinguish nontoxic NPs ("harmless NPs") from current widely used NPs.

We grouped the potential risk of NPs, based on toxicity to many kinds of bacteria [38-41], into four categories: (1) toxic at any concentration less than $1 \mathrm{mg} / \mathrm{L}$; (2) toxic at any concentrations less than $10 \mathrm{mg} / \mathrm{L}$; (3) toxic only at concentrations $>10 \mathrm{mg} / \mathrm{L}$; and (4) nontoxic at all tested concentrations (Figure 8). Details for the studies are provided in Supplemental Table 1 (see Supplementary Material available online at http://dx.doi.org/10.1155/2016/8608567). We considered the following aspects to determine whether NPs are "harmless NPs.”

4.1. Dissolution and Ion Release. $\mathrm{Ag}, \mathrm{CuO}, \mathrm{ZnO} \mathrm{NPs}$, and CdSe QDs demonstrated high toxicity to microorganisms, and it is noteworthy that metal ions released from metallic NPs played a key role in mediating the toxicity. Radniecki et al. [42] found that $20 \mathrm{~nm} \mathrm{Ag} \mathrm{NPs} \mathrm{were} \mathrm{more} \mathrm{toxic} \mathrm{than}$ $80 \mathrm{~nm} \mathrm{Ag} \mathrm{NPs,} \mathrm{which} \mathrm{was} \mathrm{attributed} \mathrm{to} \mathrm{the} \mathrm{higher} \mathrm{release}$ rate of $\mathrm{Ag}^{+}$from the smaller particles. Similarly, smaller $\mathrm{ZnO}$ NPs $(8 \mathrm{~nm})$ were found to display greater growth inhibition to $S$. aureus than larger particles $(>1 \mu \mathrm{m})$ [43]. These findings were in concordance with the study from Sadeghi et al. [44] who investigated the influence of different NPs shapes (rods, spherical particles) on bacterial toxicity. It concluded that an increased surface area resulted in increased release of $\mathrm{Ag}^{+}$ which could explain the increased toxicity of Ag NPs.

4.2. ROS. Toxicity of NPs cannot always be explained by particle dissolution and release of metallic ions $[45,46]$. In 

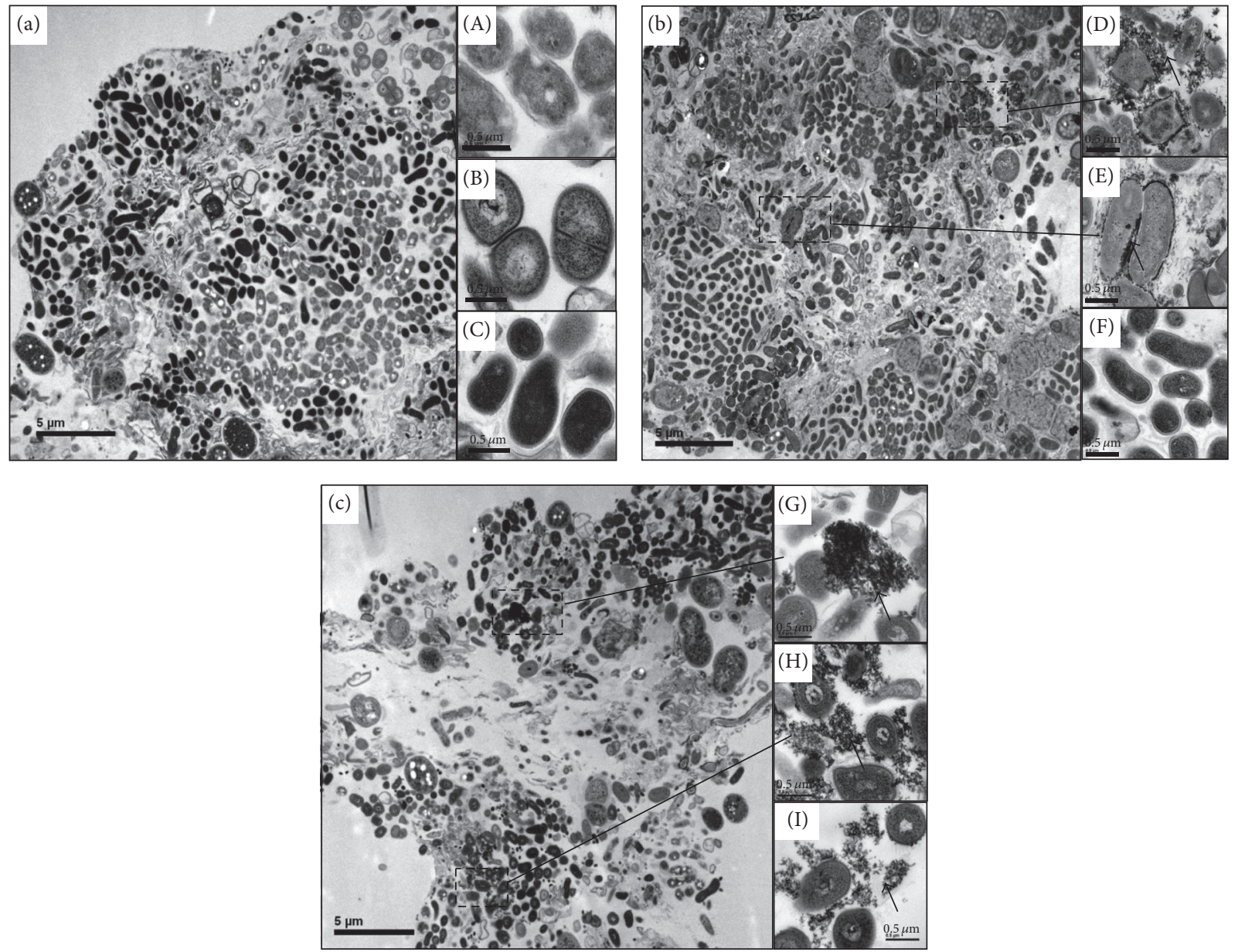

Figure 5: TEM image of sludge without (a) or with (b) the addition of $50 \mathrm{mg} / \mathrm{L} \mathrm{Fe}_{2} \mathrm{O}_{3}$ NPs after $6 \mathrm{~h}$. (a) Inset panels (A)-(C) and (D)-(F) show three kinds of bacteria in the sludge. In panel (c), the reaction was allowed to continue for 36 hours in the presence of $\mathrm{Fe}_{2} \mathrm{O}_{3} \mathrm{NP}$. The insets $(\mathrm{G})-(\mathrm{I})$ show bacteria at the $36 \mathrm{~h}$ time point. Arrows indicate $\mathrm{Fe}_{2} \mathrm{O}_{3} \mathrm{NPs}$.

these cases, ROS-mediated toxicity is widely thought to be the mechanism [47-50]. Large amount of ROS could be generated from small amounts of $\mathrm{ZnO}$ or $\mathrm{CuO} \mathrm{NPs}$ [51]. In our study, $\mathrm{Si}$ and $\mathrm{Fe}_{2} \mathrm{O}_{3}$ NPs induced the increase of ROS production at first 2 hours and then dramatically decreased to normal level. We speculate that the increased production of ROS was matched in the case of $\mathrm{Si}$ and $\mathrm{Fe}_{2} \mathrm{O}_{3}$ NPs by the stress response of bacteria and only the continuous high ROS can cause cellular damage [52].

4.3. Type of Organisms. The toxicity values of $\mathrm{SiO}_{2} \mathrm{NPs}_{\text {s varied }}$ greatly. Jiang et al. [23] found $\mathrm{SiO}_{2} \mathrm{NPs}(20 \mathrm{~nm})$ caused a high death rate for E. coli (58\%) and did not detect any ions released from NPs. They concluded that the observed toxicity of $\mathrm{SiO}_{2} \mathrm{NPs}$ resulted from their nano-size-related properties. In contrast, $\mathrm{SiO}_{2}$ NPs (10-20 nm, amorphous) doses up to 150 milligram per gram total suspended solids $(\mathrm{mg} / \mathrm{g}$ TSS) showed no inhibitory effect on waste activated sludge anaerobic digestion [53]. Hence $\mathrm{SiO}_{2} \mathrm{NPs}$ showed different toxicity to different organisms.
4.4. Photocatalysis. Toxicity of $\mathrm{TiO}_{2} \mathrm{NPs}$ might be attributed to their photocatalytic activity. $\mathrm{TiO}_{2}$ is a photocatalyst and promotes generation of ROS by interaction with photons in the ultraviolet spectrum. Several studies of toxicity $\mathrm{TiO}_{2} \mathrm{NPs}$ were conducted under ambient laboratory lighting which contains negligible or no UV radiation. It is important to note that energy at wavelength at or below $368 \mathrm{~nm}$ accounts for approximately $6 \%$ of the sunlight energy reaching the earth's surface (although this varies depending on atmospheric conditions) [54]. As such, other studies have documented that toxicity of $\mathrm{TiO}_{2} \mathrm{NPs}$ was significantly enhanced under natural sunlight [55] as compared to laboratory fluorescent lighting or dark.

4.5. Physicochemistry. Biological effects of NPs are dependent on several factors including NP physicochemistry, dose, contact time, type of organisms, and composition of growth medium [56]. However, the potential toxicity to organisms in the presence of variable environment could be dependent on the physicochemistry of NPs' characteristics [57]. Particle 


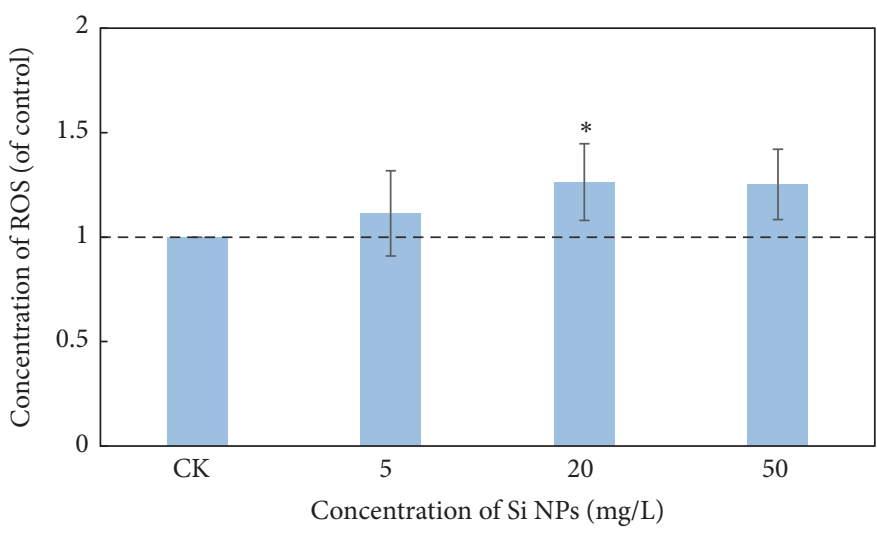

(a)

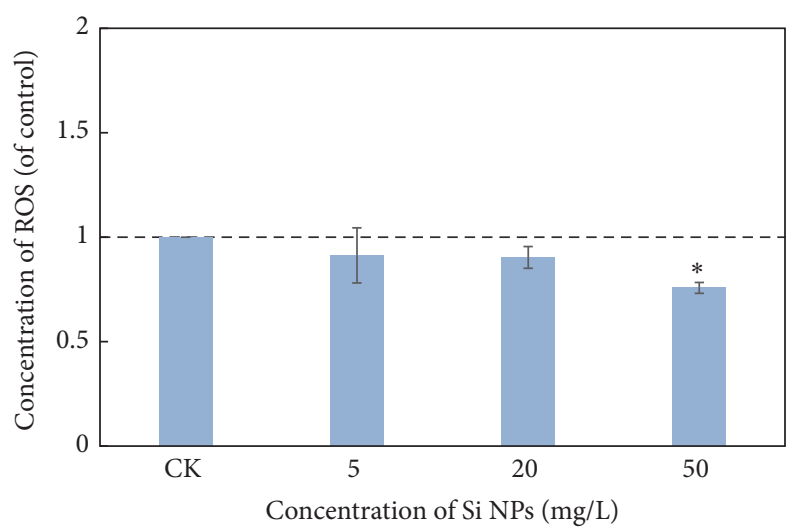

(c)

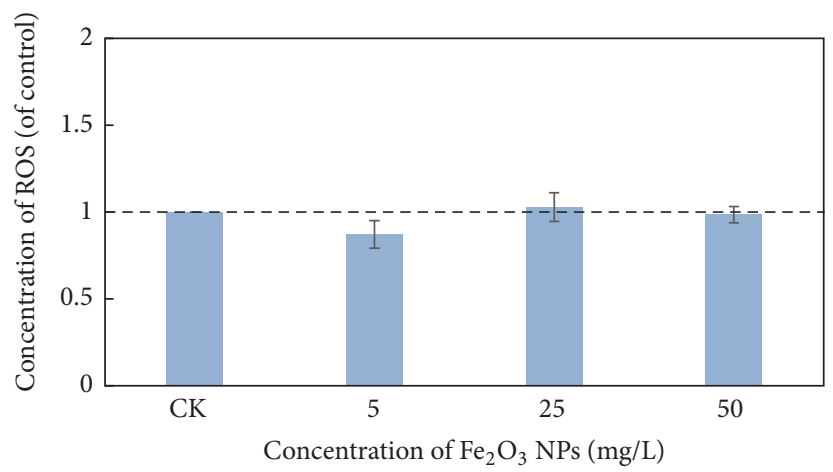

(e)

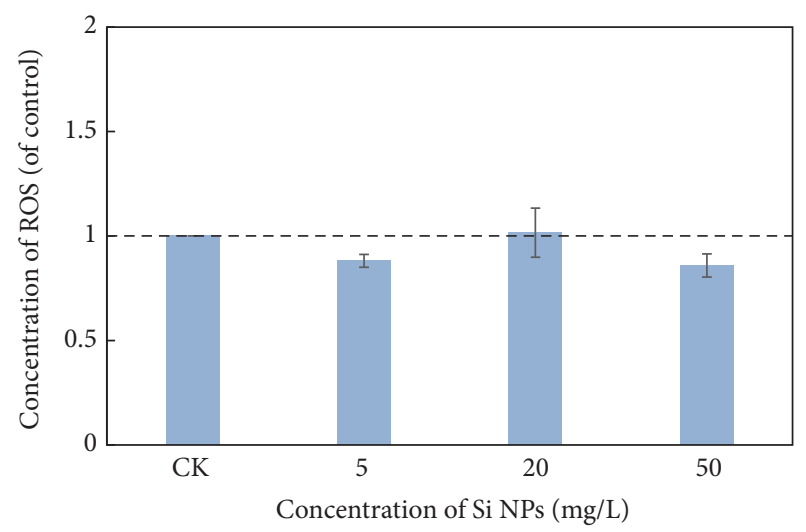

(b)

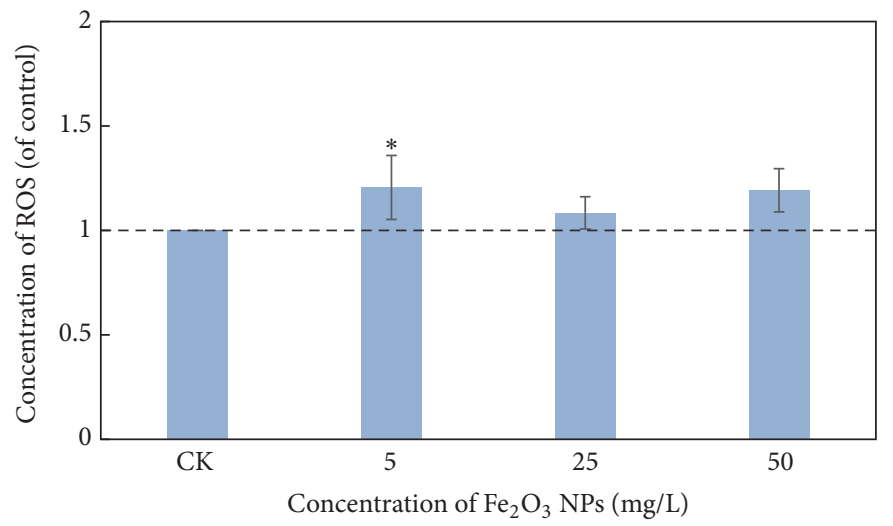

(d)

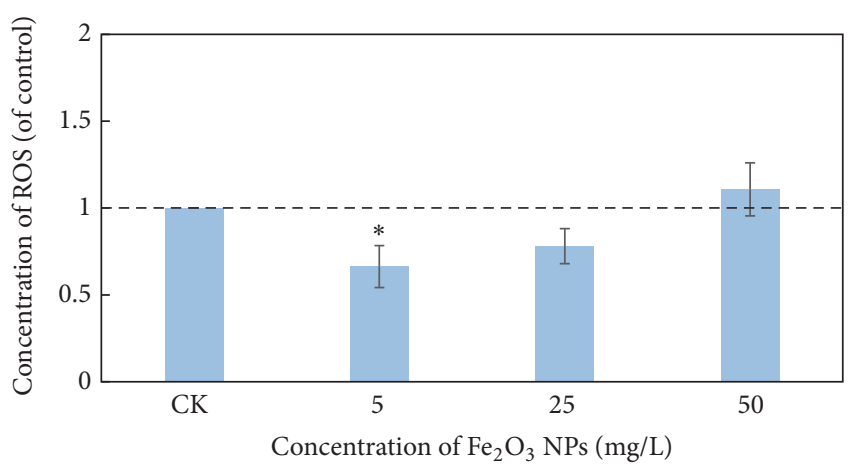

(f)

FIGURE 6: ROS concentrations at $2 \mathrm{~h}$ in various reactor cycles in the presence of Si NPs (a, b, and c) or Fe $\mathrm{O}_{3} \mathrm{NPs}(\mathrm{d}, \mathrm{e}$, and $\mathrm{f}$ ). (a, d) Cycle $1,(b, e)$ cycle 3 , and (c, f) cycle 6 . The error bars represent standard deviations from the mean. Asterisks indicate a statistically significant difference $(p=0.05)$ between the treatment and control groups.

size and shape are known to affect the organisms and NPs interaction [58]. Several studies have demonstrated that NPs always showed more serious toxicity than bulks [59-61] and suggested that particle size was one of the key factors influencing the toxic effect of NPs. $10 \mathrm{~nm} \mathrm{Ag} \mathrm{NPs} \mathrm{induced}$ more apoptotic cells than the larger particles (i.e., 50 and $100 \mathrm{~nm}$ ) [62]. The size of NPs is directly correlated with many essential properties, such as solubility, surface property, chemical reactivity, and nanoparticle-cell interaction that later affect the toxicological behaviors of NPs [63-65]. In other words, decreasing of NPs size resulted in increasing of NPs specific surface area, which increased the reactivity and enhanced interactions between NPs and organisms [34]. NPs can easily enter into the human cell or bacteria due to their tiny size $[66,67]$.

Besides size, shape of NPs is another key factor that determined NPs toxicity. For example, the truncated triangular form of Ag NPs was found to have the strongest bactericidal effect on E. coli, compared with spherical or rod-shaped form [68]. Rod- and sphere-shape of $\mathrm{TiO}_{2}$ are more phototoxic 


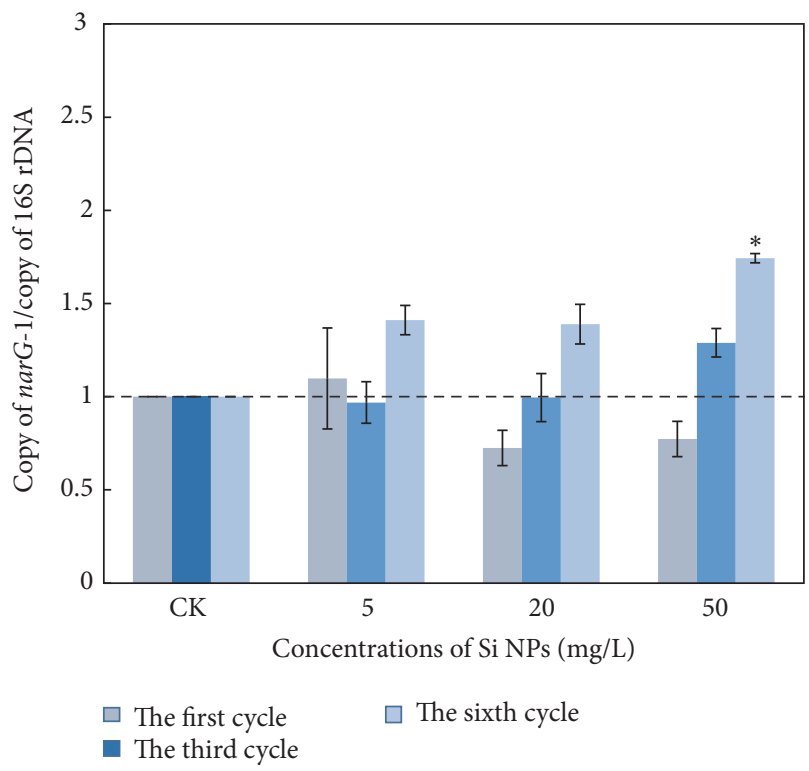

(a)

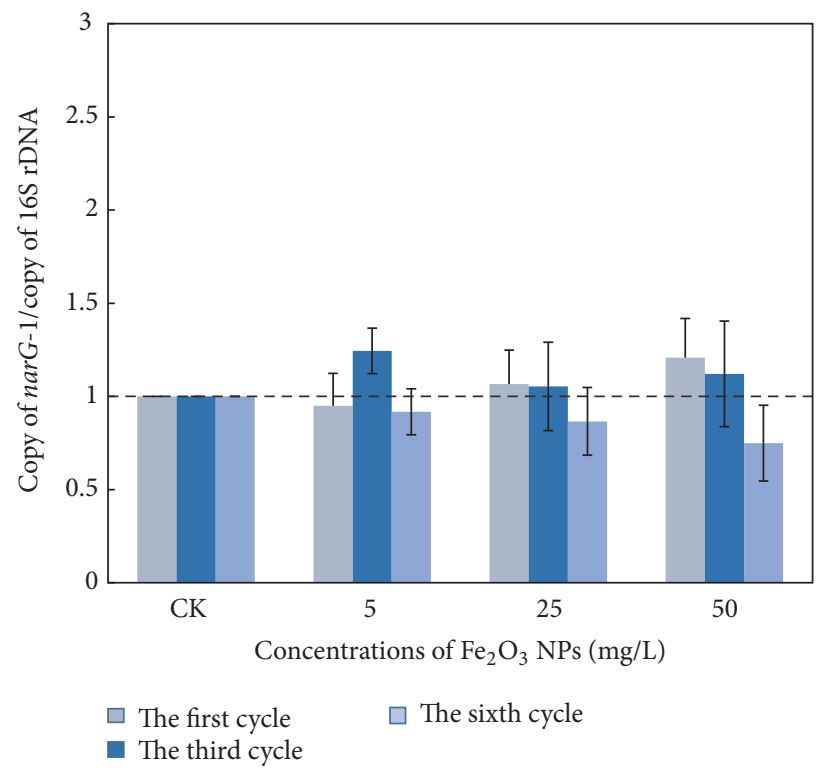

(b)

Figure 7: Quantitation of narG-1 transcript levels in reactors. We used RT-PCR to determine the amount of target gene narG-1 in the reactors with different concentrations of Si NPs (a). Similarly we measured the amount of target gene narG-1 in the reactors with different concentrations of $\mathrm{Fe}_{2} \mathrm{O}_{3}$ NPs (b). The error bars represent standard deviations from the mean. Asterisks indicate a statistical difference $(p=0.05)$ between that treatment and the control group.

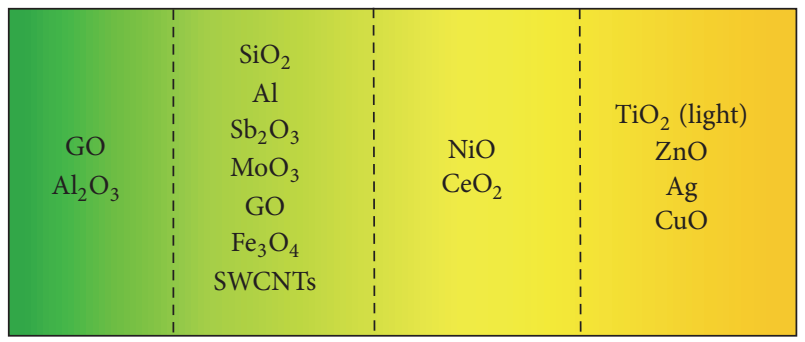

Nontoxic

Toxic at any concentration up to $10 \mathrm{mg} / \mathrm{L}$

Toxic at concentrations $>10 \mathrm{mg} / \mathrm{L}$

toxic at any concentration up to $1 \mathrm{mg} / \mathrm{L}$

FIgURE 8: Different toxic levels of different NPs.

than $\mathrm{TiO}_{2}$ nanotubes and nanosheets [50]. Material morphology influences NPs toxicity by governing how NPs align at the organisms' surface.

We conclude that the essential characteristics of "harmless NPs" are as follows: (1) the size of the nanoparticles should be $>100 \mathrm{~nm}$, (2) the nanoparticles should have no photocatalytic activity, (3) the nanoparticles should not generate toxic ions in solution, and (4) the nanoparticles should be highly crystalline.

\section{Conclusions}

We studied the effects of $\mathrm{Si}$ and $\mathrm{Fe}_{2} \mathrm{O}_{3}$ NPs on denitrification in a wastewater treatment model system. They did not cause inhibitory effects on biological nitrate removal. According to the results of TEM imaging, ROS, and the abundance of narG-1 gene, Si NPs and $\mathrm{Fe}_{2} \mathrm{O}_{3}$ NPs were nontoxic to anoxic sludge. Si NPs and $\mathrm{Fe}_{2} \mathrm{O}_{3}$ NPs might be considered as "harmless NPs" with regard to denitrification. A definition of "harmless NPs" based on physicochemical properties is needed for future applications in nanotechnology. We have made predictions about the properties of "harmless NPs" based on the literature; however, toxicological experiments should be carried out prior to wide production and application of NPs.
Abbreviations
NP: Nanoparticle
TEM: Transmission electron microscopy
WWTP: Wastewater treatment plants
DLS: Dynamic light scattering
SBR: $\quad$ Sequencing batch reactors
MLSS: Mixed liquor suspended solids
DO: Dissolved oxygen
DI: $\quad$ Deionized
ROS: Reactive oxygen species
MIC: Minimum inhibitory concentration
$\mathrm{LD}_{50}: \quad$ Median lethal dose
$\mathrm{EC}_{50}$ : Half maximal effective concentration
$\mathrm{IC}_{50}$ : Half maximal inhibitory concentration
TSS: $\quad$ Total suspended solids.

\section{Competing Interests}

The authors declare that there is no conflict of interests regarding the publication of this paper. 


\section{Acknowledgments}

The authors appreciate the National Natural Science Foundation of China (no. 50908209) for providing funding support for this project. And this project was also supported by the Innovative Research Team in Higher Educational Institutions of Zhejiang Province (no. T200912).

\section{References}

[1] S. Eduok, B. Martin, R. Villa, A. Nocker, B. Jefferson, and F. Coulon, "Evaluation of engineered nanoparticle toxic effect on wastewater microorganisms: current status and challenges," Ecotoxicology and Environmental Safety, vol. 95, pp. 1-9, 2013.

[2] O. Choi, C.-P. Yu, G. E. Fernández, and Z. Hu, "Interactions of nanosilver with Escherichia coli cells in planktonic and biofilm cultures," Water Research, vol. 44, no. 20, pp. 6095-6103, 2010.

[3] R. Brayner, R. Ferrari-Iliou, N. Brivois, S. Djediat, M. F. Benedetti, and F. Fiévet, "Toxicological impact studies based on Escherichia coli bacteria in ultrafine $\mathrm{ZnO}$ nanoparticles colloidal medium," Nano Letters, vol. 6, no. 4, pp. 866-870, 2006.

[4] D. F. Rodrigues and M. Elimelech, "Toxic effects of singlewalled carbon nanotubes in the development of E. Coli biofilm," Environmental Science and Technology, vol. 44, no. 12, pp. 45834589, 2010.

[5] Y. Ma, L. Kuang, X. He et al., "Effects of rare earth oxide nanoparticles on root elongation of plants," Chemosphere, vol. 78, no. 3, pp. 273-279, 2010.

[6] T.-H. Chung, S.-H. Wu, M. Yao et al., "The effect of surface charge on the uptake and biological function of mesoporous silica nanoparticles in 3T3-L1 cells and human mesenchymal stem cells," Biomaterials, vol. 28, no. 19, pp. 2959-2966, 2007.

[7] F. Gottschalk, T. Sonderer, R. W. Scholz, and B. Nowack, "Modeled environmental concentrations of engineered nanomaterials $\left(\mathrm{TiO}_{2}, \mathrm{ZnO}, \mathrm{Ag}, \mathrm{CNT}\right.$, fullerenes) for different regions," Environmental Science \& Technology, vol. 43, no. 24, pp. 9216-9222, 2009.

[8] M. A. Kiser, P. Westerhoff, T. Benn, Y. Wang, J. Pérez-Rivera, and K. Hristovski, "Titanium nanomaterial removal and release from wastewater treatment plants," Environmental Science \& Technology, vol. 43, no. 17, pp. 6757-6763, 2009.

[9] O. Bondarenko, K. Juganson, A. Ivask, K. Kasemets, M. Mortimer, and A. Kahru, "Toxicity of $\mathrm{Ag}, \mathrm{CuO}$ and $\mathrm{ZnO}$ nanoparticles to selected environmentally relevant test organisms and mammalian cells in vitro: a critical review," Archives of Toxicology, vol. 87, no. 7, pp. 1181-1200, 2013.

[10] X. Zheng, R. Wu, and Y. Chen, "Effects of ZnO nanoparticles on wastewater biological nitrogen and phosphorus removal," Environmental Science \& Technology, vol. 45, no. 7, pp. 28262832, 2011.

[11] A. García, L. Delgado, J. A. Torà et al., "Effect of cerium dioxide, titanium dioxide, silver, and gold nanoparticles on the activity of microbial communities intended in wastewater treatment," Journal of Hazardous Materials, vol. 199-200, pp. 64-72, 2012.

[12] X. Zheng, Y. Chen, and R. Wu, "Long-term effects of titanium dioxide nanoparticles on nitrogen and phosphorus removal from wastewater and bacterial community shift in activated sludge," Environmental Science \& Technology, vol. 45, no. 17, pp. 7284-7290, 2011.

[13] M. Kikumoto, Y. Mizuno, N. Adachi et al., "Effect of $\mathrm{SiO}_{2}$ and $\mathrm{Al}_{2} \mathrm{O}_{3}$ on the synthesis of $\mathrm{Fe}_{2} \mathrm{O}_{3}$ red pigment," Journal of the Ceramic Society of Japan, vol. 116, no. 1350, pp. 247-250, 2008.
[14] L. Xi, S. R. Grobmyer, G. Zhou, W. Qian, L. Yang, and H. Jiang, "Molecular photoacoustic tomography of breast cancer using receptor targeted magnetic iron oxide nanoparticles as contrast agents," Journal of Biophotonics, vol. 7, no. 6, pp. 401-409, 2014.

[15] F. M. Hilty, M. Arnold, M. Hilbe et al., "Iron from nanocompounds containing iron and zinc is highly bioavailable in rats without tissue accumulation," Nature Nanotechnology, vol. 5, no. 5, pp. 374-380, 2010.

[16] X. He, F. Liu, L. Liu, T. Duan, H. Zhang, and Z. Wang, "Lectinconjugated $\mathrm{Fe}_{2} \mathrm{O}_{3} @$ Au core@ shell nanoparticles as dual mode contrast agents for in vivo detection of tumor," Molecular Pharmaceutics, vol. 11, no. 3, pp. 738-745, 2014.

[17] Y. Jing, J. Liu, W.-H. Ji et al., "Biocompatible Fe-Si nanoparticles with adjustable self-regulation of temperature for medical applications," ACS Applied Materials \& Interfaces, vol. 7, no. 23, pp. 12649-12654, 2015.

[18] M. J. Dykstra and L. E. Reuss, Biological Electron Microscopy: Theory, Techniques, and Troubleshooting, Springer Science \& Business Media, 2011.

[19] C. J. Smith, D. B. Nedwell, L. F. Dong, and A. M. Osborn, "Diversity and abundance of nitrate reductase genes (narG and napA), nitrite reductase genes (nirS and $n r f A$ ), and their transcripts in estuarine sediments," Applied and Environmental Microbiology, vol. 73, no. 11, pp. 3612-3622, 2007.

[20] K. J. Livak and T. D. Schmittgen, "Analysis of relative gene expression data using real-time quantitative PCR and the $2^{-\triangle \Delta C T}$ method," Methods, vol. 25, no. 4, pp. 402-408, 2001.

[21] A. Apha, WEF, Standard methods for the examination of water and wastewater, 1998.

[22] D. H. Everett, Basic Principles of Colloid Science, Royal Society of Chemistry, London, UK, 1988.

[23] W. Jiang, H. Mashayekhi, and B. Xing, "Bacterial toxicity comparison between nano- and micro-scaled oxide particles," Environmental Pollution, vol. 157, no. 5, pp. 1619-1625, 2009.

[24] M. Jiang, Y. Zhang, X. Zhou, Y. Su, M. Zhang, and K. Zhang, "Simultaneous carbon and nutrient removal in an airlift loop reactor under a limited filamentous bulking state," Bioresource Technology, vol. 130, pp. 406-411, 2013.

[25] T. J. Brunner, P. Wick, P. Manser et al., "In vitro cytotoxicity of oxide nanoparticles: comparison to asbestos, silica, and the effect of particle solubility," Environmental Science \& Technology, vol. 40, no. 14, pp. 4374-4381, 2006.

[26] X. Zheng, Y. Su, and Y. Chen, "Acute and chronic responses of activated sludge viability and performance to silica nanoparticles," Environmental Science \& Technology, vol. 46, no. 13, pp. 7182-7188, 2012.

[27] H. Herd, N. Daum, A. T. Jones, H. Huwer, H. Ghandehari, and C.-M. Lehr, "Nanoparticle geometry and surface orientation influence mode of cellular uptake," ACS Nano, vol. 7, no. 3, pp. 1961-1973, 2013.

[28] J. Gao, Y. Wang, A. Hovsepyan, and J.-C. J. Bonzongo, "Effects of engineered nanomaterials on microbial catalyzed biogeochemical processes in sediments," Journal of Hazardous Materials, vol. 186, no. 1, pp. 940-945, 2011.

[29] Z. Sheng and Y. Liu, "Effects of silver nanoparticles on wastewater biofilms," Water Research, vol. 45, no. 18, pp. 6039-6050, 2011.

[30] B. Wu, Y. Wang, Y.-H. Lee et al., "Comparative eco-toxicities of nano- $\mathrm{ZnO}$ particles under aquatic and aerosol exposure modes," Environmental Science \& Technology, vol. 44, no. 4, pp. 1484-1489, 2010. 
[31] T. Xia, M. Kovochich, M. Liong et al., "Comparison of the mechanism of toxicity of zinc oxide and cerium oxide nanoparticles based on dissolution and oxidative stress properties," ACS Nano, vol. 2, no. 10, pp. 2121-2134, 2008.

[32] A. Nel, T. Xia, L. Mädler, and N. Li, “Toxic potential of materials at the nanolevel," Science, vol. 311, no. 5761, pp. 622-627, 2006.

[33] S. George, S. Pokhrel, T. Xia et al., "Use of a rapid cytotoxicity screening approach to engineer a safer zinc oxide nanoparticle through iron doping," ACS Nano, vol. 4, no. 1, pp. 15-29, 2010.

[34] S.-R. Chae, M. Therezien, J. F. Budarz et al., "Comparison of the photosensitivity and bacterial toxicity of spherical and tubular fullerenes of variable aggregate size," Journal of Nanoparticle Research, vol. 13, no. 10, pp. 5121-5127, 2011.

[35] N. G. Howlett and S. V. Avery, "Induction of lipid peroxidation during heavy metal stress in Saccharomyces cerevisiae and influence of plasma membrane fatty acid unsaturation," Applied and Environmental Microbiology, vol. 63, no. 8, pp. 2971-2976, 1997.

[36] A. Shanmuganathan, S. V. Avery, S. A. Willetts, and J. E. Houghton, "Copper-induced oxidative stress in Saccharomyces cerevisiae targets enzymes of the glycolytic pathway," FEBS Letters, vol. 556, no. 1-3, pp. 253-259, 2004.

[37] D. Y. Lyon and P. J. J. Alvarez, "Fullerene water suspension (nC60) exerts antibacterial effects via ROS-independent protein oxidation," Environmental Science and Technology, vol. 42, no. 21, pp. 8127-8132, 2008.

[38] L. K. Adams, D. Y. Lyon, and P. J. J. Alvarez, "Comparative ecotoxicity of nanoscale $\mathrm{TiO}_{2}, \mathrm{SiO}_{2}$, and $\mathrm{ZnO}$ water suspensions," Water Research, vol. 40, no. 19, pp. 3527-3532, 2006.

[39] Y.-W. Baek and Y.-J. An, "Microbial toxicity of metal oxide nanoparticles $\left(\mathrm{CuO}, \mathrm{NiO}, \mathrm{ZnO}\right.$, and $\left.\mathrm{Sb}_{2} \mathrm{O}_{3}\right)$ to Escherichia coli, Bacillus subtilis, and Streptococcus aureus," Science of the Total Environment, vol. 409, no. 8, pp. 1603-1608, 2011.

[40] J. Ma, X. Quan, X. Si, and Y. Wu, "Responses of anaerobic granule and flocculent sludge to ceria nanoparticles and toxic mechanisms," Bioresource Technology, vol. 149, pp. 346-352, 2013.

[41] X. Hu, S. Ouyang, L. Mu, J. An, and Q. Zhou, "Effects of graphene oxide and oxidized carbon nanotubes on the cellular division, microstructure, uptake, oxidative stress, and metabolic profiles," Environmental Science and Technology, vol. 49, no. 18, pp. 10825-10833, 2015.

[42] T. S. Radniecki, D. P. Stankus, A. Neigh, J. A. Nason, and L. Semprini, "Influence of liberated silver from silver nanoparticles on nitrification inhibition of Nitrosomonas europaea," Chemosphere, vol. 85, no. 1, pp. 43-49, 2011.

[43] N. Jones, B. Ray, K. T. Ranjit, and A. C. Manna, "Antibacterial activity of $\mathrm{ZnO}$ nanoparticle suspensions on a broad spectrum of microorganisms," FEMS Microbiology Letters, vol. 279, no. 1, pp. 71-76, 2008.

[44] B. Sadeghi, F. S. Garmaroudi, M. Hashemi et al., "Comparison of the anti-bacterial activity on the nanosilver shapes: nanoparticles, nanorods and nanoplates," Advanced Powder Technology, vol. 23, no. 1, pp. 22-26, 2012.

[45] D. Lin and B. Xing, "Root uptake and phytotoxicity of $\mathrm{ZnO}$ nanoparticles," Environmental Science and Technology, vol. 42, no. 15 , pp. 5580-5585, 2008.

[46] S. Manzo, A. Rocco, R. Carotenuto et al., "Investigation of $\mathrm{ZnO}$ nanoparticles' ecotoxicological effects towards different soil organisms," Environmental Science and Pollution Research, vol. 18, no. 5, pp. 756-763, 2011.
[47] K. Pulskamp, S. Diabaté, and H. F. Krug, "Carbon nanotubes show no sign of acute toxicity but induce intracellular reactive oxygen species in dependence on contaminants," Toxicology Letters, vol. 168, no. 1, pp. 58-74, 2007.

[48] E. M. Hotze, J. Labille, P. Alvarez, and M. R. Wiesner, "Mechanisms of photochemistry and reactive oxygen production by fullerene suspensions in water," Environmental Science \& Technology, vol. 42, no. 11, pp. 4175-4180, 2008.

[49] H. Yang, C. Liu, D. Yang, H. Zhang, and Z. Xi, "Comparative study of cytotoxicity, oxidative stress and genotoxicity induced by four typical nanomaterials: the role of particle size, shape and composition," Journal of Applied Toxicology, vol. 29, no. 1, pp. 69-78, 2009.

[50] T. Tong, A. Shereef, J. Wu et al., "Effects of material morphology on the phototoxicity of nano- $\mathrm{TiO}_{2}$ to bacteria," Environmental Science and Technology, vol. 47, no. 21, pp. 12486-12495, 2013.

[51] Y. Toduka, T. Toyooka, and Y. Ibuki, "Flow cytometric evaluation of nanoparticles using side-scattered light and reactive oxygen species-mediated fluorescence-correlation with genotoxicity," Environmental Science and Technology, vol. 46, no. 14, pp. 7629-7636, 2012.

[52] T. Xia, M. Kovochich, and A. Nel, “The role of reactive oxygen species and oxidative stress in mediating particulate matter injury," Clinics in Occupational and Environmental Medicine, vol. 5, no. 4, pp. 817-836, 2006.

[53] H. Mu, Y. Chen, and N. Xiao, "Effects of metal oxide nanoparticles $\left(\mathrm{TiO}_{2}, \mathrm{Al}_{2} \mathrm{O}_{3}, \mathrm{SiO}_{2}\right.$ and $\left.\mathrm{ZnO}\right)$ on waste activated sludge anaerobic digestion," Bioresource Technology, vol. 102, no. 22, pp. 10305-10311, 2011.

[54] S. A. Diamond, G. S. Peterson, J. E. Tietge, and G. T. Ankley, "Assessment of the risk of solar ultraviolet radiation to amphibians. III. Prediction of impacts in selected northern midwestern wetlands," Environmental Science and Technology, vol. 36, no. 13, pp. 2866-2874, 2002.

[55] T. P. Dasari, K. Pathakoti, and H.-M. Hwang, "Determination of the mechanism of photoinduced toxicity of selected metal oxide nanoparticles ( $\mathrm{ZnO}, \mathrm{CuO}, \mathrm{Co}_{3} \mathrm{O}_{4}$ and $\mathrm{TiO}_{2}$ ) to E. coli bacteria," Journal of Environmental Sciences, vol. 25, no. 5, pp. 882-888, 2013.

[56] D. M. Aruguete and M. F. Hochella Jr., "Bacteria-nanoparticle interactions and their environmental implications," Environmental Chemistry, vol. 7, no. 1, pp. 3-9, 2010.

[57] S. K. Brar, M. Verma, R. D. Tyagi, and R. Y. Surampalli, "Engineered nanoparticles in wastewater and wastewater sludgeevidence and impacts," Waste Management, vol. 30, no. 3, pp. 504-520, 2010.

[58] Y. Ge, J. P. Schimel, and P. A. Holden, "Evidence for negative effects of $\mathrm{TiO}_{2}$ and $\mathrm{ZnO}$ nanoparticles on soil bacterial communities," Environmental Science and Technology, vol. 45, no. 4, pp. 1659-1664, 2011.

[59] K. Kasemets, A. Ivask, H.-C. Dubourguier, and A. Kahru, "Toxicity of nanoparticles of $\mathrm{ZnO}, \mathrm{CuO}$ and $\mathrm{TiO}_{2}$ to yeast Saccharomyces cerevisiae," Toxicology in Vitro, vol. 23, no. 6, pp. 1116$1122,2009$.

[60] O. Bondarenko, A. Ivask, A. Käkinen, and A. Kahru, "Subtoxic effects of $\mathrm{CuO}$ nanoparticles on bacteria: kinetics, role of $\mathrm{Cu}$ ions and possible mechanisms of action," Environmental Pollution, vol. 169, pp. 81-89, 2012.

[61] K. Kasemets, S. Suppi, K. Künnis-Beres, and A. Kahru, “Toxicity of $\mathrm{CuO}$ nanoparticles to yeast saccharomyces cerevisiae BY4741 wild-type and its nine isogenic single-gene deletion mutants," Chemical Research in Toxicology, vol. 26, no. 3, pp. 356-367, 2013. 
[62] T.-H. Kim, M. Kim, H.-S. Park, U. S. Shin, M.-S. Gong, and H.W. Kim, "Size-dependent cellular toxicity of silver nanoparticles," Journal of Biomedical Materials Research Part A, vol. 100, no. 4, pp. 1033-1043, 2012.

[63] Y. Zhao, H. Meng, Z. Chen, F. Zhao, and Z. F. Chai, "Dependence of nanotoxicity on nanoscale characteristics and strategies for reducing and eliminating nanotoxicity," in Nanotoxicology, Y. L. Zhao and H. S. Nalwa, Eds., pp. 265-280, American Scientific, Stevenson Ranch, Calif, USA, 2007.

[64] A. Albanese, C. D. Walkey, J. B. Olsen, H. Guo, A. Emili, and W. C. W. Chan, "Secreted biomolecules alter the biological identity and cellular interactions of nanoparticles," ACS Nano, vol. 8, no. 6, pp. 5515-5526, 2014.

[65] A. B. Djurišić, Y. H. Leung, A. M. C. Ng et al., "Toxicity of metal oxide nanoparticles: mechanisms, characterization, and avoiding experimental artefacts," Small, vol. 11, no. 1, pp. 26-44, 2015.

[66] R. Stelzer and R. J. Hutz, "Gold nanoparticles enter rat ovarian granulosa cells and subcellular organelles, and alter in-vitro estrogen accumulation," Journal of Reproduction and Development, vol. 55, no. 6, pp. 685-690, 2009.

[67] W.-R. Li, X.-B. Xie, Q.-S. Shi, H.-Y. Zeng, Y.-S. Ou-Yang, and Y.-B. Chen, "Antibacterial activity and mechanism of silver nanoparticles on Escherichia coli," Applied Microbiology and Biotechnology, vol. 85, no. 4, pp. 1115-1122, 2010.

[68] S. Pal, Y. K. Tak, and J. M. Song, "Does the antibacterial activity of silver nanoparticles depend on the shape of the nanoparticle? A study of the gram-negative bacterium Escherichia coli," Applied and Environmental Microbiology, vol. 73, no. 6, pp. 17121720, 2007. 

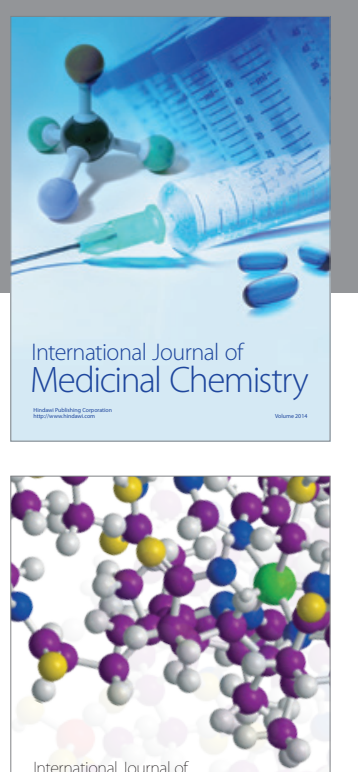

Carbohydrate Chemistry

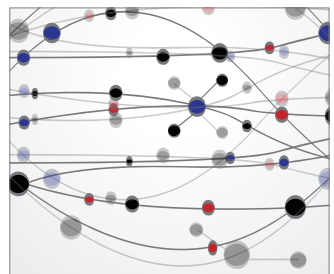

The Scientific World Journal
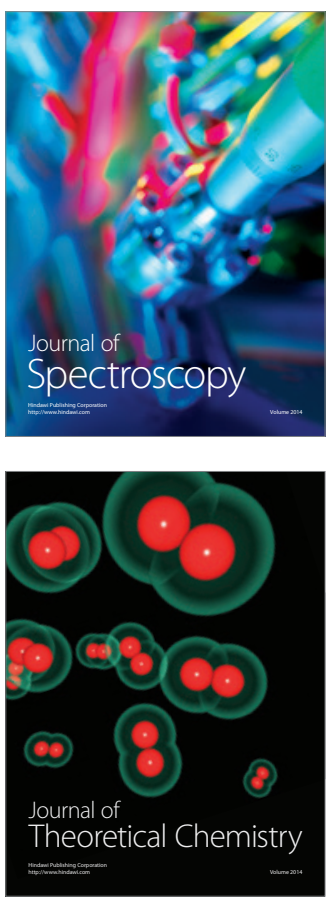
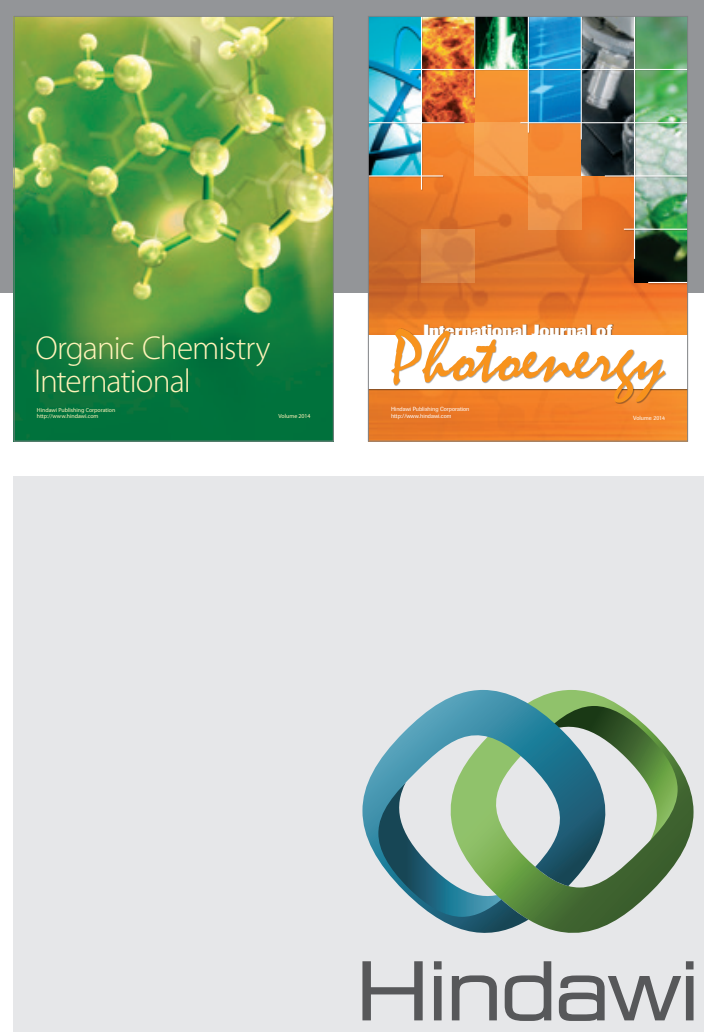

Submit your manuscripts at

http://www.hindawi.com

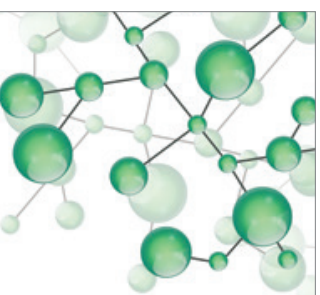

International Journal of

Inorganic Chemistry

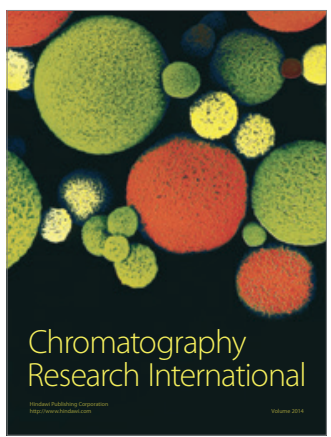

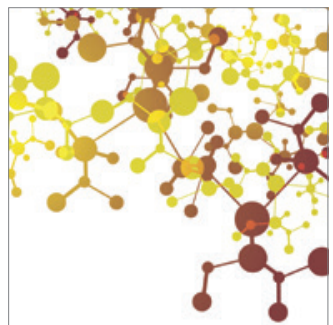

Applied Chemistry
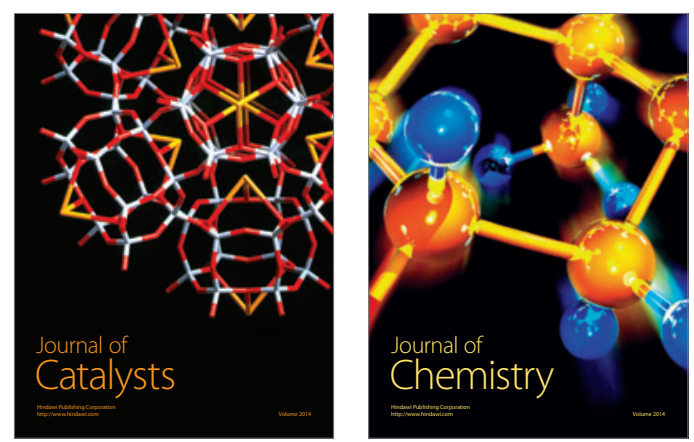
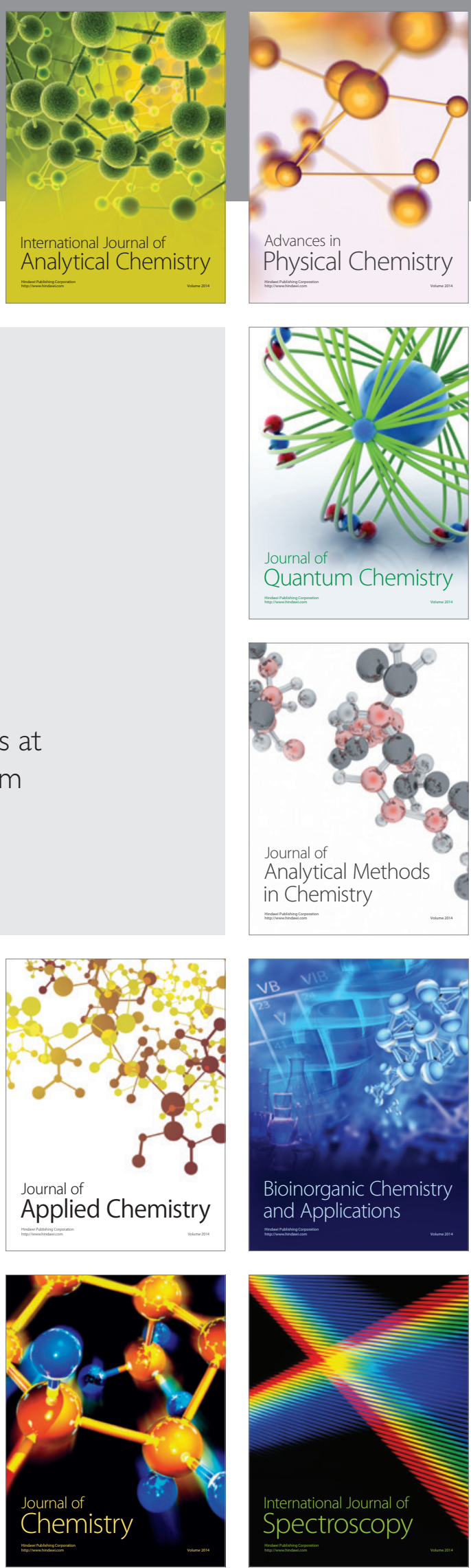